\title{
KAJIAN YURIDIS TERHADAP PERATURAN MAHKAMAH AGUNG NOMOR 2 TAHUN 2015 TENTANG TATA CARA PENYELESAIAN GUGATAN SEDERHANA
}

\author{
Salman Alfarasi \\ Hakim Pengadilan Negeri Tanjungkarang Lampung \\ Email : salman.natasaad@gmail.com
}

\begin{abstract}
ABSTRAK
Peraturan Mahkamah Agung Republik Indonesia Nomor 2 Tahun 2015 tentang tata cara penyelesaian gugatan sederhana yang dikeluarkan oleh Mahkamah Agung Republik Indonesia merupakan salah satu terobosan hukum di bidang Hukum acara Perdata. Substansi fundamental Perma ini adalah adanya pemangkasan proses dalam tahapan beracara, sehingga proses pemeriksaan dan penyelesaiannya dapat dilakukan secara lebih cepat dan sederhana sehingga para pencari keadilan tidak perlu menunggu waktu yang terlalu lama untuk mendapatkan keadilan, kemanfatan dan kepastian hukum. Namun dalam telaah teoritis, kehadiran Perma ini menimbulkan konsekuensi yuridis yang tidak dapat diabaikan begitu saja, terutama berkenaan dengan pertentangan antara asas keadilan dan asas kepastian hukum.
\end{abstract}

Kata Kunci : Peraturan Mahkamah Agung, Asas Keadilan, Asas Kepastian Hukum

\section{ABSTRACT}

The Regulation of the Supreme Court of the Republic of Indonesia Number 2 Year 2015 on the procedure for settling a simple lawsuit issued by the Supreme Court of the Republic of Indonesia is one of the legal breakthroughs in the field of Civil Code Law. The fundamental substance of this Perma is the pruning of processes in the stages of the ceremony, so that the process of examination and resolution can be done more quickly and simply so that justice seekers do not have to wait too long to get justice, advantage, and legal certainty. Nevertheless in theoretical analysis, the presence of this Perma has juridical consequences which can not be ignored, especially with regard to the contradiction between the principles of justice and the principle of legal certainty.

Keywords: Supreme Court Regulation, Principle of Justice, Principle of Legal Certaint 


\section{Pendahuluan}

Kiranya tidak berlebihan apabila Penn mengungkapkan bahwa "to delay justice is injustice" (Penn, 1905). Ungkapan kegelisahan Penn tersebut mengandung maksud bahwasanya proses peradilan yang berjalan saat ini begitu menyita waktu hingga berlarutlarut, melalui tahapan yang berbelitbelit, dan cenderung memakan biaya tinggi sehingga nalar awam mengatakan bahwa kondisi tersebut berkontribusi signifikan terhadap adanya ketidakpastian hukum serta pengaburan atas esensi keadilan hukum yang hendak dicari oleh para pencari keadilan itu sendiri. Untuk itu, sudah sepatutnya sistem peradilan yang ada segera berbenah baik dari sisi administratifprosedural maupun dari sisi akuntabilitas institusi peradilan (Hammergren;2002). Bertalian dengan hal tersebut, guna menyelenggarakan sistem peradilan dalam kerangka menegakkan hukum dan keadilan berdasarkan Pancasila dan UndangUndang Dasar Negara Republik Indonesia Tahun 1945 (selanjutnya disingkat Konsitusi UUD 1945) sebagai manifestasi riil terselenggaranya Negara Hukum Republik Indonesia maka selanjutnya hakikat, kandungan, makna, dan tafsir filosofis dari asas kepastian hukum, kemanfaatan hukum, dan keadilan hukum kemudian dicoba untuk ditangkap oleh pemerintah melalui pengundangan Undang-Undang Republik Indonesia Nomor 48 Tahun 2009 tentang Kekuasaan Kehakiman (selanjutnya disingkat UU Kehakiman).

Secara khusus, di dalam pasal 2 ayat (4) UU Kehakiman menyebutkan bahwa peradilan dilakukan dengan sederhana, cepat, dan biaya ringan, di mana ketentuan ini kemudian menjadi salah satu asas fundamental di dalam sistem peradilan di Indonesia. Dengan mendalilkan kepada pendapat Mertokusumo bahwasanya asas hukum atau prinsip hukum bukan sebagai peraturan hukum konkrit, melainkan merupakan, pikiran dasar yang umum sifatnya atau merupakan latar belakang dari peraturan yang konkrit yang terdapat dalam dan di belakang setiap sistem hukum yang terjelma dalam peraturan perundang-undangan dan putusan hakim yang merupakan hukum positif dan dapat diketemukan dengan mencari sifat-sifat umum dari peraturan konkrit tersebut (Sudikno Mertokusumo, 2007;34). Untuk itu, dalam rangka membuka akses seluasluasnya kepada masyarakat dalam hal mencari keadilan hukum, oleh karena itu pada hakikatnya asas sederhana, cepat, dan biaya ringan mengandung maksud bahwa proses peradilan yang ada harus melalui proses yang tidak berbelit-belit, acaranya jelas, mudah dipahami, dan terpenuhi adanya biaya terjangkau oleh masyarakat tingkat bawah sekalipun (Hairi;2011).

Pada perkembangan selanjutnya, eksistensi pengimplementasian sistem peradilan yang berlandaskan kepada asas sederhana, cepat, dan biaya ringan, kemudian ditegaskan kembali melalui Rencana Pembangunan Jangka Menengah Nasional 2015-2019, di mana disebutkan bahwa dalam rangka mewujudkan daya saing tersebut, pembangunan hukum nasional perlu diarahkan untuk mendukung terwujudnya pertumbuhan ekonomi yang berkelanjutan; mengatur permasalahan yang berkaitan dengan ekonomi, terutama dunia usaha dan industri; serta menciptakan kepastian investasi, terutama penegakan dan perlindungan hukum. Oleh karena itu diperlukan strategi secara sistematis terhadap revisi peraturan perundangundangan di bidang hukum perdata 
secara umum maupun khusus terkait hukum kontrak, perlindungan Hak Kekayaan Intelektual, pembentukan penyelesaian sengketa acara cepat (small claim court), dan peningkatan utilisasi lembaga mediasi (Kementerian Perencanaan Pembangunan Nasional/ Badan Perencanaan Pembangunan Nasional, 2014). Berkenaan dengan penyelesaian sengketa acara cepat (small claim court) dalam ranah hukum perdata, Mahkamah Agung kemudian merespon secara saksama hal tersebut dengan dikeluarkannya Peraturan Mahkamah Agung Nomor 2 Tahun 2015 tentang Tata Cara Penyelesaian Gugatan Sederhana (selanjutnya disingkat Perma 2/2015).

Mendasarkan kepada telaah akademis penulis, kehadiran Perma 2/2015 ini memiliki kemaslahatan bagi para pihak dan sekaligus juga membawa beberapa konsekuensi yuridis yang tidak dapat diabaikan begitu saja. Pada sisi positif, manfaat dengan dikeluarkannya Perma 2/2015 adalah pemangkasan proses dalam tahapan beracara, sehingga proses pemeriksaan dan penyelesaian perkara dapat dilakukan secara lebih cepat dan sederhana. Hal ini dimaksudkan agar para pencari keadilan dalam ruang lingkup keperdataan tidak perlu menunggu waktu yang terlalu lama untuk mendapatkan kepastian hukum dari sengketa yang tengah dihadapi karena proses penyelesaiannnya cukup disidangkan dan berakhir di pengadilan tingkat pertama. Pada sisi yang bersamaan, Mahkamah Agung secara tidak langsung juga mendapatkan manfaat atas pembatasan tersebut karena dengan dipangkasnya upaya hukum yang berjalan dipastikan akan menekan jumlah tumpukan perkara perdata yang masuk untuk disidangkan. Namun pada sisi yang berlawanan, penulis berpendapat bahwa Perma 2/2015 juga mengandung beberapa kelemahan pada tataran teoritis. Kelemahan pertama, adalah persoalan penafsiran 'sederhana'. Disebutkan dalam Pasal 1 angka 1 Perma 2/2015 bahwa penyelesaian gugatan sederhana adalah tata cara pemeriksaan di persidangan terhadap gugatan perdata dengan nilai gugatan materiil paling banyak Rp. 200.000.000 (dua ratus juta rupiah) yang diselesaikan dengan tata cara dan pembuktian sederhana. Penulis berpandangan bahwa tafsir terhadap istilah 'sederhana' yang dianalogikan dengan nilai gugatan materiil $\mathrm{Rp}$. 200.000.000 (dua ratus juta rupiah) adalah tidak memiliki argumentasi yuridis yang kuat, sebab tidak semua nilai gugatan materiil Rp. 200.000.000 (dua ratus juta rupiah) dapat dikategorikan sebagai perkara sederhana. Adakalanya gugatan materiil perkara yang nilainya di bawah angka Rp. 200.000.000 (dua ratus juta rupiah) namun justru sulit dan rumit dalam proses pembuktian di persidangan. Begitupun sebaliknya, terdapat juga gugatan yang nilainya di atas angka $\mathrm{Rp}$. 200.000.000 (dua ratus juta rupiah) namun lebih mudah dan sederhana dalam proses pembuktiannya di persidangan. Lebih lanjut, seiring dengan perkembangan nilai mata uang dan perubahan tingkat ekonomi masyarakat yang berjalan begitu dinamis di Indonesia, sangat dimungkinkan bahwasanya gugatan materiil yang nilainya di angka $\mathrm{Rp}$. 200.000.000 (dua ratus juta rupiah) sudah tidak relevan lagi dikategorikan lagi ke dalam penafsiran perkara sederhana.

Kelemahan kedua adalah berkaitan dengan persoalan domisili para pihak yang berperkara. Sebagaimana disebutkan di dalam Pasal 4 ayat (3) 
Perma 2/2015 bahwasanya penggugat dan tergugat dalam gugatan sederhana wajib berdomisili di daerah hukum pengadilan yang sama. Apabila dikaji lebih dalam, maka persoalan domisili para pihak tentunya berbenturan dengan konsideran dari Perma 2/2015 itu sendiri sebab rumusan ketentuan ini membatasi akses seluas-luasnya kepada masyarakat dalam mencari hal keadilan hukum. Sebagai contoh misalnya, ketika terjadi perjanjian antara konsumen dengan sebuah produsen di kantor cabang. Manakala terjadi sengketa atau perselisihan hukum perdata, pada umumnya produsen kantor cabang akan diwakili oleh produsen kantor pusat yang berada di domilisi hukum yang berbeda dan tentunya tidak berada pada domisili hukum yang sama pada saat perjanjian dibuat pertama kali, sehingga hal ini secara otomatis akan menggugurkan hak konsumen dalam memperoleh akses kepada keadilan melalui opsi penyelesaian gugatan sederhana.

Kelemahan ketiga adalah berkaitan dengan sistem norma. Sebagaimana mendalilkan kepada pendapat Kelsen bahwa sistem hukum merupakan himpunan dari norma-norma hukum yang dibentuk oleh organ pemegang kekuasaan, baik secara langsung maupun tidak langsung, dengan melandaskan kepada norma dasar (basic norm). Dalam pemikiran Kelsen, keberadaan norma dasar (basic norm) berperan dalam membimbing tentang bagaimana setiap orang/badan hukum seharusnya bersikap atau berperilaku sesuai dengan ketentuan-ketentuan yang telah ditetapkan oleh konstitusi serta menjamin koherensi internal antara norma-norma hukum yang berada di dalam sistem hukum itu sendiri (prinsip non-kontradiksi) (Hans Kelsen, 1949). Sejalan dengan prinsip non-kontradiksi di dalam sistem norma hukum maka norma-norma hukum yang berada di dalam ruang lingkup sistem hukum kemudian diatur, disusun, dan dirumuskan sedemikian rupa secara berjenjang dan bertingkat secara selaras dan harmoni guna menghindari kontradiksi antar norma hukum. Pada tataran nasional, pengaturan norma hukum secara berjenjang dan harmonis ini kemudian diatur di dalam UndangUndang Republik Indonesia Nomor 12 Tahun 2011 tentang Pembentukan Peraturan Perundang-undangan (selanjutnya disingkat UU PPPU).

Bertalian dengan persoalan sistem norma, apabila mengkaji di dalam pasal 1 angka 3 Perma 2/2015 disebutkan bahwa hakim adalah hakim tunggal. Dalam pengamatan sekilas, terobosan hukum ini seolah tidak menjadi permasalahan serius dan sejalan reformasi sistem peradilan dengan tujuan penyelesaian gugatan sederhana yang cepat dan tidak memerlukan mekanisme yang berbelit-belit. Namun demikian, penulis berpendapat bahwa pengaturan terkait dengan hakim tunggal di dalam Perma 2/2015 sejatinya bertentangan dengan UU Kekuasaan Kehakiman atau dalam bahasa sederhana bahwasanya keberadaan Perma 2/2015 secara nyata telah melanggar prinsip pengaturan norma hukum yang selaras dan berjenjang sebagaimana diatur di dalam UU PPPU. Dalam analisis penulis, mendalilkan kepada regulasi yang ada maka komposisi jumlah hakim yang menangani suatu perkara sudah diatur terlebih dahulu melalui Pasal 11 ayat (1) UU Kekuasaan Kehakiman bahwasanya Pengadilan memeriksa, mengadili, dan memutus perkara dengan susunan majelis sekurang-kurangnya 3 (tiga) orang hakim, kecuali undang-undang menentukan lain. Interpretasi terhadap 
pasal tersebut secara nyata menjelaskan mengenai pengecualian terhadap ketentuan susunan majelis hakim. Sebagai contoh undang-undang yang menentukan lain di sini adalah jumlah hakim dalam pengadilan anak. Berdasarkan Pasal 11 ayat (1), Pasal 14 ayat (1), Pasal 18 ayat (1) UndangUndang Nomor 3 Tahun 1997 tentang Pengadilan Anak maupun Pasal 44 ayat (1), Pasal 47 ayat (1), dan Pasal 50 ayat (1) Undang-Undang Nomor 11 Tahun 2012 tentang Sistem Peradilan Pidana Anak, hakim memeriksa dan memutus perkara anak baik dalam tingkat pertama, tingkat banding, maupun tingkat kasasi dengan hakim tunggal. Dengan demikian, dari penjelasan di atas dapat diketahui bahwa pada dasarnya hakim saat memeriksa dan memutus perkara sebagaimana diatur dalam UU Kekuasaan Kehakiman sekurang-kurangnya berjumlah 3 (tiga) orang. Namun bisa jadi kurang atau lebih dari tiga orang, sesuai dengan jenis perkara yang diadili dan diputus oleh hakim yang bersangkutan serta sudah diatur dengan undang-undang. Pada titik kesimpulan, keberadaan Perma 2/2015 sebagaimana diatur di dalam penjelasan Pasal 79 Undang-Undang Republik Indonesia Nomor 3 Tahun 2009 tentang Perubahan Kedua Atas Undang-Undang Nomor 14 Tahun 1985 tentang Mahkamah Agung (selanjutnya disingkat UU MA) bahwa Perma ditujukan hanya untuk mengisi kekosongan hukum. Pengaturan mengenai Perma sendiri tidak dapat melumpuhkan norma hukum yang telah diatur undang-undang artinya tidak mungkin peraturan yang lebih rendah menegasikan berlakunya norma hukum yang kedudukannya lebih tinggi, sehingga dapatlah dikatakan menjadi tidak logis dan tidak harmonis apabila kemudian pengaturan hakim tunggal sebagaimana dirumuskan di dalam Perma 2/2015 tersebut ternyata justru bertentangan dan menabrak norma hukum yang berada di atasnya.

Kelemahan keempat adalah berkenaan dengan proses beracara mulai dari pendaftaran berkas perkara sampai dengan pelaksanaan eksekusi. Sebagai contoh adalah persoalan penetapan hari sidang dan pemanggilan para pihak. Mencermati pada jangka waktu beracara yang relatif singkat, penulis berpandangan apakah pihak tergugat dapat menyiapkan dokumen dan bukti-bukti sehubungan dengan proses pemeriksaan secara tepat. Para pengacara saja dalam mempersiapkan kebutuhan sidangnya bisa cukup lama, apalagi kalau ternyata tergugat ini tidak didampingi sama sekali oleh pengacara. Pihak penggugat tentu dalam hal ini akan lebih diuntungkan karena proses penyiapan yang lebih lama sehingga asumsinya posisinya lebih siap dengan materi gugatannya. Lebih lanjut, berkesuaian dengan salah satu asas di dalam hukum acara perdaata yaitu asas audi et alteram partem bahwa hakim harus mendengar kedua belah pihak secara proporsional, maka sepatutnya pihak tergugat diberikan waktu lebih lama untuk memberikan jawaban. Persoalan mengenai jangka waktu ini apabila secara tidak proporsional diakomodir tentunya dikhawatirkan dapat menciderai prinsip-prinsip keadilan terutama kepada pihak tergugat.

Persoalan selanjutnya adalah mekanisme pendaftaran kasus yang tidak mengatur mengenai pilihan acara para pihak. Apakah para pihak bisa memilih acara pemeriksaannya sendiri ataukah dipaksakan oleh ketua pengadilan. Apakah suatu kasus yang masuk harus diadili dengan skema sederhana atau biasa ditentukan secara 
sepihak. Konsep acara yang dirumuskan di dalam Perma 2/2015 ini memang menyerupai konsep hukum acara pidana yang mengenal tiga model pemeriksaan suatu perkara yakni acara singkat, acara cepat dan acara biasa. Akan tetapi sengketa dalam wilayah hukum perdata tidak bisa disikapi seperti halnya kasus pidana. Apabila perkara perdata berkaitan erat dengan strategi hukum para pihak, akan tetapi perkara pidana lebih kental dengan intervensi/kepentingan penguasa (kepolisian). Dalam perkara perdata, ada pihak yang menginginkan bahwa kasus tertentu diperlama karena terkait dengan strategi hukum para pihak dalam penyelesaian masalah dan ada juga yang menginginkan cepat selesai. Maka dari itu, pengadilan sebaiknya memberikan ruang kepada para pihak yang bersengketa untuk memilih skema penyelesaiannya sendiri.

Persoalan terakhir adalah pelaksanaan eksekusi. Sebagai diketahui bahwa akhir dari sengketa perdata adalah putusan hakim berkuatan hukum tetap (inkracht van gewijsde) yang dinantikan oleh para pihak yang tengah bersengketa, di mana putusan hakim atau disebut juga dengan istilah putusan pengadilan sepatutnya merefleksikan pada asas keadilan hukum, asas kepastian hukum, dan sekaligus juga asas kemanfaatan hukum secara berimbang dan proporsional. Menjadi menarik manakala, kajian teoritis terhadap Perma 2/2015 berkaitan dengan pelaksanaan ekseksusi justru menimbulkan ketidakpastian hukum. Penulis memandang bahwa pangkal persoalan ini terletak pada pasal 31 ayat (3) Perma 2/2015, di mana apabila pelaksanaan eksekusi tidak dapat dijalankan dengan sukarela maka pelaksanaan eksekusi terhadap putusan hakim dilaksanakan berdasarkan ketentuan hukum acara perdata yang berlaku. Tentunya kandungan maksud dari pasal 31 ayat (3) Perma 2/2015 di sini secara tidak langung justru bertentangan dengan ruh dan semangat diterbitkannya Perma 2/2015 itu sendiri yaitu untuk mewujudkan penyelesaian sengketa yang cepat dan sederhana. Bahkan guna menghindari penyelesaian perkara yang berlarutlarut, ditegaskan dalam ketentuan pasal 17 Perma 2/2015 bahwasanya di dalam proses pemeriksaan gugat sederhana sejatinya telah menegasikan keberadaan hukum acara perdata itu sendiri yaitu tidak dapat diajukan tuntutan provisi, eksepsi, rekonvensi, intervensi, replik, duplik, atau kesimpulan.

Pada titik kesimpulan, muatan substansial dari Perma 2/2015 ini berusaha meniadakan ketentuan hukum acara perdata yang lazim dipergunakan dalam mekanisme penyelesaian perkara perdata, namun pada satu yang sama Perma 2/2015 juga memberlakukan ketentuan hukum acara perdata. Penulis memandang terkait dengan penghapusan beberapa ketentuan di dalam hukum acara perdata secara tidak langung berorientasi kepada adanya kepastian hukum, namun cenderung tidak berpihak kepada asas keadilan hukum. Sementara pelaksanaan putusan eksekusi yang tetap menggunakan ketentuan hukum acara perdata pada satu sisi merefleksikan asas keadilan hukum, namun pada sisi berlawanan justru meminggirkan eksistensi asas kepastian hukum.

\section{A. RUMUSAN MASALAH}

Bertitik tolak dari sekilas latar belakang permasalahan di atas, maka permasalahan pokok dalam artikel ini adalah untuk menguraikan Apakah Pelaksanaan Eksekusi Gugatan Sederhana sudah merepresentasikan asas Kepastian Hukum 
Pembahasan

\section{Pelaksanaan Putusan terhadap Gugatan sederhana.}

Putusan pengadilan dilaksanakan setelah berkekuatan hukum tetap. Dalam perkara gugatan sederhana putusan berkekuatan hukum karena tidak diajukan keberatan sampai dengan jangka waktu yang ditentukan berdasarkan Pasal 22 ayat (1) Perma 2/2015 dan putusan keberatan itu sendiri. Perma memberikan dua pilihan dalam pelaksanaan putusan yaitu dilaksanakan secara sukarela, maka putusan dilaksanakan berdasarkan hukum acara perdata yang berlaku.

Dalam halputusan dilaksanakan secara sukarela, maka pihak yang dinyatakan kalah melakukan apa yang diperintahkan dalam amar putusan. Jika putusan berisi menghukum Tergugat untuk membayar sejumlah uang kepada Penggugat, maka setelah dilaksanakan pembayara secar penuh atau diakui oleh penggugat bahwa pembayaran yang dilakukan sebagai bentuk pelaksanaan putusan, maka perkara diantara para pihak dianggap telah selesai.

A. Pelaksanaan Putusan Secara Sukarela

Pelaksanaan Pasal 31 ayat (2) menyebutkan bahwa putusan yang sudah berkekuatan hukum tetap dilaksanakan secara sukarela. Ketentuan tersebut dibuat untuk memberikan kesempatan terlebih dahulu kepada Tergugat yang dinyatakan kalah untuk melaksanakan isi putusan secara sukarela, karena dengan pelaksanaan putusan secara suka rela akan mengurangi dampak kerugian sosial seperti perasaan malu dan tercemaar mana baiknya atas pelaksanaan putusan secara paksa, disamping itu pelaksanaan secara sukarela akan mengurangi kerugian secara ekonomi bagi pihak Tergugat akibat biaya-biaya ekekusi yag akan dibebankan pada hasil penjualan lelang barang milik Tergugat.

Pelaksanaan isi putusan secara sukarela dilakukan berdasarkan beberapa kemungkinan antara lain:

- Tergugat yang dinyatakan kalah melaksanaan semua apa yang diperintahkan oleh putusan;

- Tergugat yang dinyatakan kalah melaksanakan sebagian dari yang diperintahkan, amun Penggugat menyetujuinya dan dianggap telah melaksanakan isi putusan;

- Tergugat yang dinyatakan kalah melakukan tindakan lain yang berbeda dengan apa yang diperintahkan dalam putusan namun disetujui oleh Penggugat sebagai pelaksanaan isi putusan;

Tehadap putusan yang telah dilaksanakan secara sukarela, maka setelah tergugat melaksanakan isi putusan kemudian para pihak melaporkan kepada ketua pengadilan bahwa isi putusan telah dilaksanakan secara sukarela dan kemudian akan dibuatkan berita acara pelaksanaan putusan sebagai bukti bahwa putusan telah dilaksanakan.

\section{Pelaksanaan Putusan Secara Paksa}

> Putusan dilaksanakan berdasarkan Hukum Acara Perdata yang Berlaku Berdasarkan Pasal31 ayat (3) bahwa dalam hal Tergugat tidak mau melaksanakan isi putusan secara sukarela, maka putusan dilaksanakan berdasarkan ketentuan hukum acara perdata yang berlaku. Putusan yang telah berkekuatan hukum tetap dilaksanakan berdasarkan ketentuan Pasal 195 HIR sebagai berikut:

(1) Keputusan hakim dalam perkara yang pada tingkat pertama diperiksa oleh Pengadilan Negeri dilaksanakan atas perinth dan di 
bawah pimpinan Ketua Pengadilan Negeri yang memeriksa perkara itu menurut cara yang diatur dalam pasalpasal berikut;

(2) Jika keputusan itu haru dilaksanakan seluruhnya atau sebagian diluar daerah hukum Pengadilan Negeri tersebut, maka ketuanya akan meminta bantuan dengan surat kepada Ketua Pengadilan Negeri yang berhak begitu juga halnya pelaksanaan putusan diluar Jawa dan Madura;

(3) Ketua Pengadilan Negeri yang diminta antuan itu harus bertindak menurut ketentuan ayat di atas jika nyata baginya bahwa keputusan itu harus dilaksanakan seluruhnya atau sebagian di luar daerah hukumnya;

(4) Bagi ketua Pengadilan Negeri yang diminta bantuannya oleh teman sejawatnya di luar Jawa dan Madura berlaku segera peraturan dalam bagian ini tentang segala perbuatan yang akan dilakukan karena permintaan itu;

(5) Dalam dua kali dua puluh empat jam ketua yang diminta bantuan itu harus memberitahukan segala usaha yang telah diperintahkan dan hasilnya kepada Ketua Pengadilan Negeri yang mulamula memeriksa perkara itu;

(6) Jika pelaksaan putusan itu dilawan, juga perlawanan itu dilakukan oleh orang lain yang mengakui barang yang disita itu sebagi miliknya, maka hal itu serta segala perselisihan tentang upaya paksa yang diperintahkan itu, diajukan kepada dan diputusakan oleh Pengadilan Negeri yang dalam daerah hukumnya harus dilaksanakan keputusan itu;

(7) Perselisihan dan keputusan tentang perselisihan itu, tiap dua kali dua puluh empat jam harus diberitahukan dengan surat oleh Ketua Pengadilan Negeri yang mula-mula memeriksa perkara itu.

Berdasarkan ketentuan Pasal 195 HIR di atas dapat disimpulkan beberapa hal tentang kompetensi pengadilan dalam melakukan eksekusi putusan antara lain:

- Pengadilan yang berwenang melaksanakan putusan hakim yang telah berkekuatan hukum tetap adalah pengadilan yang memeriksa dan menjatuhkan tentang sengketa yang dimohonkan eksekusi tersebut.

- Jika ternyata objek yang akan dieksekusi berada di wilayah hukum pengadilan lain, maka ketua pengadilan yang dimohonkan eksekusi oleh pihak yang menang, akan meminta bantuan (delegasi) eksekusi kepada ketua pengadilan dimana objek eksekusi tersebut berada;

- Jika permintaan bantuan (delegasi) eksekusi itu berasal dari pengadilan diluar Jawa dan Madura, maka yang berlaku adalah ketentuan eksekusi yang diatur dalam HIR;

- Dalam waktu dua hari setelah dilaksanakan permintaan eksekusi tersebut ketua pengadilan yang dimintakann delegasi eksekusi harus memberitahukan kepada ketua pengadilan yang memeriksa perkara yang dimintakan eksekusi;

- Jika ada perlawanan, maka perlawanana itu diajukan di pengadilan yang menjalankan eksekusi; 
- Dalam waktu dua hari setelah diputuskan tentang perlawanan itu ketua pengadilan tempat diajukannya perlawanan harus memberitahukan hasilnya kepada ketua yang memeriksa perkara yang dimohonkan eksekusi;

$>$ Penggugat Mengajukan

Permohonan Eksekusi

Penggugat yang dinyatakan menang harus mengajukan permohonan pelaksanan putusan (eksekusi) kepada ketua pengadilan di tempat perkara tersebut diputus. Berdasarkan permohonan tersebut ketua pengadilan akan mengeluarkan penetapan pemeritah pelaksanaan putusan yang selanjutnya akan dilaksanakan oleh panitera dan jurus sita berdasarkan tahapan-tahapan eksekusi.

Putusan dalam perkara tidak dapat dijalankan tanpa adanya permohonan dari pihak Penggugat yang dinyatakan menang.Permohonan dibuat dalam bentuk surat yang ditandatangani oleh pemohon eksekusi atau kuasanya dengan melampirkan putusan yang telah berkekuatan hukum tetap.

Ketua pengadilan akan memeriksa isi putusan apakah benar putusan yang dimintakan eksekusi tersebut telah berkekutan hukum tetap dan mengandung amar kondemnator yang dapat dilaksanakan. Setelah dapat dipastikan bahwa putusan dapat dilaksanaka melalui prosedur eksekusi, ketua pengadilan mengeluarkan penetapan perintah eksekusi.Biaya pelaksanaan eksekusi ditanggung sepenuhnya oleh Pemohon Eksekusi kecuali jika ditetapkan bahwa eksekusi dijalankan secara predo (Cuma-Cuma) karena Pemohon Eksekusi berasal dari masyarakat tidak mampu.

$>$ Ketua Pengadilan Memberikan Teguran (aanmaning)
Tahapan selanjutnya dari proses eksekusi adalah melakukan teguran (aanmaning). Ketua pengadilan memanggil pihak Termohon Eksekusi untuk ditegur terlebih dulu agar memenuhi apa yang telah ditentukan dalam putusan. Proses teguran ini sebenarnya merupakan tindakan pendahuluan sebelum selanjutnya dilakukan upaya paksa jika pihak Termohon Eksekusi tetap tidak mau melaksanakan isi putusan secara sukarela.

Pasal 196 HIR menyebutkan bahwa "jika pihak yang dikalahkan tidak mau atau alai memenuhi keputusan itu dengan baik, maka phak yang dimenangkan mengajukan permintaan kepada Ketua Pengadilan Negeri tersebut pada pasal 195 ayat (1), baik dengan lisan mauun dengan surat supaya keputusan itu dilaksanakan. Kemudian ketua itu akan memanggil pihak yag kalah itu serta menegurnya supaya ia memenuhi keputusan itu Dallam waktu yang ditentukan oleh ketua itu selamalamanya delapan hari".

Jika atas panggilan dari ketua pengadilan ternyata Termohon Eksekusi tidak datang menghadap kepadanya, maka ketidakhadiran itu harus dipertimbankan sebagai berikut:

- Jika ketidakhadiran termohon eksekusi memiliki alasan yang sah dan patut untuk dimaklumi, misalnya karena sakit atau ada halangan yang memang sangat urgen, maka ketua pengadilan harus melakukan panggilan ulang untuk yang kedua kali dengan syarat bahwa alasan ketidakhadiran itu disampaikan kepada pihak ketua pengadilan yang memanggilnya;

- Jika ketidakhadiran termohon ekseskusi tidak memiliki alasan yang sah dan patut, maka keetua 
pengadilan dapat lansung memerintahkan peletakan sita eksekusi terhadap harta kekayaan milik termohon.

Menurut M. Yahya Harahap, atas ketidakhadiran pihak TermohonEksekusi tanpa alasan yang sah maka akibatnya adalah:

1. Tidak diperlukan proses pemeriksaan sidang peringatan

2. Tidak diberikan tenggang masa peringatan dan;

3. Secara ex officio Ketua Pengadilan Negeri dapat langsung mengeluarkan surat perintah eksekusi dalam eksekusi riil atau perintah eksekutorial beslag dalam eksekusi pembayara sejumlah uang (Yahya Harahap).

> Peletakan Sita Eksekusi

Salah satu tahapan yang harus dilalui dalam jenis eksekusi pembayaran sejumlah uang (verkoop executie) adalah proses peletakan sita eksekusi (executie beslag). Penyitaan adalah prosedur yang harus dilaksanakan dalam kaitannya dengan eksekusi suatu kewajiban pembayaran sejumlah uang, berbeda halya dengan eksekusi riil (Eksekusi riil dalah bentuk eksekusi yang sifatnya melakukan tindakan nyata sebagaimana yang diperintahkan dalam amar putusan yang bersifat condemnatoir) yang tidak membutuhkan proses sita eksekusi. Jika sebelumnya pernah diletakkan sita jaminan dan dinyatakan sah dan berharga dalam putusan, maka setelah putusan berkekuatan hukum tetap, maka demi sita jaminan menjadi sita eksekusi.

Pasal 197 HIR secara utuh menyebutkan sebagai berikut:

1. Jika sudah lewat waktu yang ditentukan itu, sedangkan orang yang kalah itu belum juga memenuhi keputusan itu, atau jika orang itu sesudah dipanggil dengan sah tidak juga menghadap, maka ketua karena jabatannya akan memberi perintah dengan surat suoaya disita sekian barang yang bergerak atau jika barang demikian tidak ada atau ternyata tidak cukup, sekian barang tak bergerak kepunyaan orang yang kalah itu sampai dianggap cukup dalam keputusan itu dan semua biaya untuk melaksanakan keputusan itu.

2. Penyitaan dijalankn oleh Panitera Pengadilan Negeri.

3. Bila Panitera itu beralangan karena tugas dinas atau karena alasan yang lain maka ia digantikan oleh seorang yang cakap atau dapat dipercaya yang ditunjuk untuk itu oleh ketua atau atas permintaannya oleh kepala pemeritahan setempat (Dallam hal ini asisten residen) dalam hal menunjuk orang itu menurut cara tersebut jika dianggap perlu menurut keadaan ketua berkuasa juga untuk menghemat ongkos sehubungan dengan jauhnya tempat penyitaan itu.

4. Penujukan orang itu dilakukan hanya dengan menyebutkan atau dengan mencatatnya dalam surat perintah pada ayat (1) pasal ini.

5. Panitera itu atau yang ditunjuk sebagai gantinya hendaklah membuat berita acara tentang tugasnya dan memberitahukan tentang maksud isi berita acara itu kepada orang yang disita barangnya itu kalau ia hadir.

6. Penyitaan itu dilakukan dengan bantuan dua orang saksi yang disebutkan namnya pekerjaannya dan tempat diamnya dalam berita acara itu dan yang menandatangani berita acara itu dan salinannya. 
7. Saksi itu harus penduduk Indonesia telah berumur 21 tahun dan dikenal oleh penyita itu sebagai orang yang dapat dipercaya atau diterangkan demikian oleh seorang pamong praja bangsa Eropa atau Indonesia.

8. Penyitaan barang bergerak milik debitor termasuk uang tunai dan barag berharga boleh juga dilakukan atas barang bergerak yang bertubuh yang ada ditangan orang lain tetapi tidak boleh dilakukan atas hewan dan perkakas yang sungguh-sungguh bergua bagi orang yang kalah bagi menjalankan mata pencahariannya sendiri.

9. Panitera atau orang yang ditunjuk menjadi penggantinya hendaklah membiarkan menurut keadaan barang bererak itu seluruhnya atau sebagian disimpan oleh orang yang disita barangnya itu atu menyuruh membawa barang itu seluruhnya atau sebagian ke suatu tempat penyimpanan yang memadai. Dalam hal pertama hal itu harus diberitahukan kepada polisi desa atau polisi kampung dan polisi itu harus menjaga supaya jangn ada barang yang dilarikan orang. Bangunan-bngunan orang Indonesia yang tidak melekat ada tanah tidak boleh dibawa ke tempat lain.

Sita eksekusi dilaksanakan berdasarkan perintah ketua pengadilan sebagai bentukrangkaian proses eksekusi jikajangka waktu teguran yang diberikan oleh ketua pengadilan tidak diindahkan oleh Termohon Eksekusi atau Termohon Eksekusi tidak datang menhadap kepada ketua pengadilan atas panggilan diberikan dalam bentuk penetapan dan atas perintah tersebut panitera atau juru sita dengan didampingi oleh dua orang sksi berangkat ke lokasi dimana benda yang menjadi objek penyitaan berada. Oleh karena proses sita eksekusi sifatnya adalah upaya paksa, maka panitera atau jurusita dapat meminta bantuan kepada pihak kepolisian untuk melakukan pengamanan jalannya proses penyitaan (D.Y. Wiranto;2013).

Proses sita eksekusi dituangkan dalam berita acara sita sehingga apa yang terjadi dalam proses penyitaan hendaknya dicatat dan dituangkan ke dalam berita acara. Dalam berita acara penyitaan setidaknya memuat hal-hal sebagai berikut antar lain:

- Identitas para pihak;

- Identitas petugas yang ditunjuk untuk melaksanakan penyitaan;

- Saksi-saksi;

- Jenis dan bentuk barang yang akan disita;

- Letak atau tempat barang yang aka disita;

- Pihak-pihak dan penjagaan barang yang disita;

- Penjelasan-penjelasan, menyangkut segala keadaan dilapangan, misalnya barangnya tidak ditemukan atau proses sita tidak dapat dijalankan dengan segala alasan penyebabnya;

- Tanggal, bulan, jam dan tahun pelaksanaan sita.

Dalam proses penyitaan pihak termohon sita tidak diharuskan hadir dilapangan, meskipun lebih baik jika pihak Termohon Sita juga bisa hadir dan segaligus menandatangani berita acara penyitaan agar tidak ada kekeliruan menyangkut barang yang menjadi objek penyitaan. Namun jika pihak termohon sita tidak hadir, maka tidak akan menghambat proses jalannya penyitaan adlah petugas yang melaksanakan penyitaan dan saksi-saksi.

Pasal 197 ayat (8) HIR menyebutkan bahwa "Penyitaan barang bergerak milik debitor termasuk uang 
tunai dan barang berharga boleh juga dilakukan atas barang bergerak yang bertubuh yang ada ditangan orang lain tetapi tidak boleh dilakukan atas hewan dan perkakas yang sungguh-sungguh berguna bagi orang yang kalah itu bagi menjalankan mata pencahariannya sendiri" Dalam paragraf terakhir pasal di atas disebutkan bahwa perkakas yang digunakan untuk menjalankan mata pencaharia tidak boleh disita, ketentuan tersebut untuk menjamin agar pihak tereksekusi bisa menlanjutkan kehidupannya, pasca pelaksanaan eksekusi.

Ketentuan Pasal 197 ayat (8) HIR pada prinsipya mengatur tentang proses eksekusi terhadap putusan pengadilan yang telah berkekuatan hukum tetap yang mana dalam amar putusan mengandung kewajiban pembayaran sejumlah uang, sehingga untuk memenuhi kewajiban tersebut barangbarang milik Tergugat yag dihukum, baik yang bergerak maupun yang tidak bergerak akan disita dan selanjutnya di lakukan penjualan secara umum (lelang) untuk memenuhi kewajiban pembayaran sejumlah uang, mulai dari barang-barang bergerak milik Tergugat dan jika bergerak sampai nilai penjualan barang-barnag tersebut mencukupi untuk membayar sejumlah uang yang dihukumkan amar putusan.

Dalam proses penyitaan benda tidak bergerak, pelaksanaan sita akan dianggap mengikat sejak diumumkan atau didaftarkan, maka terhadap proses penyitaan benda bergerak sita tersebut akan dianggap mengikat sejak berita acara pelaksnaan sita itu diberitahukan kepada pihak Termohon Eksekusi. Jika pada saat proses penyitaan itu dilakukan sekaligus saat itu juga diberitahukan kepada pihak Termohon Eksekui, namun jika pada saat penyitaan dilakukan Termohon Eksekusi tidak hadir,maka berita acara penyitaan akan disampaikan oleh jurusita kepadanya.

$>$ Penjualan Lelang

Tahapan terakhir dari seluruh rangkaian proses eksekusi adalah penjualan secara umum (lelang). Objek jaminan harus dijual secara umum (lelang). Jika atas penjulan didaptkan nilai yang lebih besar dari kewajiban yang ditanggung pihak termohon eksekusi, maka sis dan kelebihan dari hasil penjualan tersebut harus dikembalikan kepada pihak termohon eksekusi, namun jika nilai penjualan lelang lebih rendah dari nilai kewajiban yang di tanggung oleh termohon eksekusi, maka eksekusi akan dilanjutkan pada saat ditemukan kembali harta milik pihak tereksekusi.

Pengadilan dapat meminta bantuan kepada Kantor Lelang untuk melaksanakan eksekusi pelelangan. Kelengkapan dalam proses pelelangan antara lain:

- Surat Permintaan Lelang;

- Salinan Putusan Pengadilan;

- Salinan Penetapan Sita;

- Salian Berita Acara Sita;

- Salinan Penetapan Lelang;

- Salinan Surat Pemberitahuan Lelang kepada pihak yang berkepentingan;

- Perincian besarnya jumlh tagihan pokokditamah biaya yang dibebankan kepada Tergugat(Tereksekusi);

- Bukti Kepemilikan (serifikat) barang yang hendak dijual lelang atas barang yang tidak bergerak, Surat Bukti Kepemilikan yang belum mempunyai sertifikat dapat diganti misalnya dengan surat keterangan dari Kepala Desa setempat; 
- Syarat-syarat Lelang yang ditentukan penjual lelang; dan

- Bukti Pengumuman Lelang yang dikeluarkan Pengadilan Negeri (Yahya Harahap;1991).

Kantor lelang akan melakaksanakan proses pelelangan berdasarkan Peraturan Menteri Keuangan RI No 27/PMK.06/2016 tentan Petunjuk Pelaksnaan Lelang. Hasil dari penjualan lelang akan diserahkan kepada Penggugat yang dinyatakan menang melalui pengadilan sebagai pelaksanaan dari amar putusan.

1. Kepastian Hukum di dalam pelaksanaan eksekusi terhadap gugatan sederhana.

Setelah Penulis melakukan Penelitian maka hambatan-hambatan yang terjadi di dalam pelaksanaan Putusan Gugatan Sederhana sebagai berikut:

a. adanya perlawanan oleh orang lain/pihak ketiga (Deden Verzet) dan Peninjauan Kembali (PK).

Upaya perlawanan ini dimungkinkan terhadap pelaksanaan putusan Gugatan Sederhana oleh karena Perma 2 Tahun 2015 tidak mengatur secara spesifik mengenai hal ini sehingga dimungkinkan diajukan Perlawanan yang akan mengakibatkan lama proses eksekusinya.

Perma 2 Tahun 2015 tentang Prosedur gugatan sederhana memberikan kemudahan bagi para pihak untuk melakukan prosedur beracara di dalam Gugatan Sederhana akan tetapi Perma tersebut belum mengatur secara khusus mengenai bagaimana tata cara mengajukan eksekusi terhadap putusan gugatan sederhana sehingga Pelaksanaan Eksekusi dilakukan melalui prosedur gugatan biasa yang membutuhkan waktu lama karena dimungkinkannya adanya perlawanan oleh orang lain/pihak ketiga dan upaya hukum Peninjauan Kembali dengan hal tersebut menjadikan pelaksaan eksekusi terhadap Putusan Gugatan sederhana menjadi hambatan di dalam prosedurnya.

b. Biaya yang wajib di bayarkan karena besarnya biaya belum terpenuhi oleh pemohon eksekusi.

Nilai Kerugian dari Gugatan sederhana adalah dibatasi dengan nilai nominal Rp. 200.000.000,00 (dua ratus juta rupiha) sehingga apabila nilai kerugian tersebut yang dikabulkan oleh Hakim lebih kecil dari biaya eksekusi menyebabkan hambatan dari pemohon eksekusi untuk membayar biaya eksekusi tersebut.

c. Hambatan Karena Bunyi/Redaksi Putusan

Adakalanya redaksi dalam surat putusan kurang jelas yang dapat menimbulkan Penafsiran yang bermacam-macam. Hal yang demikian dapat terjadi misalnya karena tergugat/kuasanya, kurang cerat dalam penyusunan redaksi Petitum gugatan sedangakan Hakimnya mengabulkan begitu saja apa yang diminta dalam Petitum gugatan tersebut.

Seperti umpamanya dalam azas putusan yang berbunyi “ Menyatakan" sebuah perusahaan/ Nama seseorang membayar kepada Penggugat sejumlah uang pada hal sebenarnnya lebih tepat "Menghukum" membayar kepada Penggugat sejumlah uang pada hal perusahaan tersebut sudah tutup dan bubar sementara nama orang tersebut bukan pengurus atau Owner perusahaan tersebut dan 
sebenarnya Hakim mempunyai kewenangan untuk memperbaiki/tata dalam lingkup Redaksional supaya dalam Hukum dapat lebih dipertanggung jawabkan.

d. Lelang Eksekusi Tidak dapat di Jalankan karena dikabulkan Bantahan Pembantah atau Lelang Eksekusi yang memerlukan biaya.

Pelaksanaan eksekusi di lapangan banyak sekali kendala terutama ketika akan dilakukan eksekusi Termohon eksekusi melakukan segala cara sehingga pelaksanaan eksekusi tersebut terhambat dengan mengajukan perlawanan dan disamping itu Proses lelang dimana pada saat penjualan lelang obyek lelang tidak ada yang mau membeli sehingga hambatan tersebut merugikan Pemohon eksekusi.

Berdasarkan hambatan-hambatan tersebut diatas, maka faktor-faktor penyebab timbulnya hambatanhambatan dalam eksekusi putusan perkara perdata, dapat kita uraikan sebagai berikut:

a. Pada umunya pihak yang kalah dalam suatu perkara tidak dengan "Sukarela" untuk melaksanakan putusan tersebut sehingga mengerahkan masa untuk menghalang-halangi eksekusi tersebut.

b. Pihak ketiga mengajukan perlawanan atas sita eksekusi, proses ini juga bisa sampai kasasi, kalu eksekusi perkara maka akan cukup lama menunggu proses teresebut di putus.

c. Dalam eksekusi dalam kasus-kasus tertentu diperlukam biaya yang harus di keluarkan oleh pemohon eksekusi cukup besar seperti mengosongkan tanah yang banyak prinsip liar yang harus dilakukan, atau membayar biaya aparat keamanan yang banyak di lapangan dengan biaya yang besar. Atau seperti putusan serta merta pemohon eksekusi harus menyiapkan jaminan sesuai atau jaminan dengan objek perkara yang mau di eksekusi. Sehingga tidak dapat di jalankan seperti seperti SEMA No. 4 Tahun 2001.

d. Penasehat Hukum/Lawyer/advokad daripemohon dalam membuat gugatan tidak Profesional sehingga putusan tidak dapat di eksekusi artinya Petitum tidak bersifat Komendenator.

e. Ada kelompok masyarakat kurang ada kesadaran hukum yang mau dibayar oleh termohon eksekusi untuk menghambat tidak jalannya eksekusi lapangan.

\section{Kesimpulan}

Mendasarkan kepada sekilas uraian tersebut di atas maka dapat disimpulkan bahwa (1) Perma 2 Tahun 2015 tentang Gugatan Sederhana belum secara tegas mengatur mengenai Pelaksanaan Eksekusi terhadap Gugatan Sederhana sehingga Pelaksanaan Eksekusi masih mengunakan Hukum Acara Perdata sebagaimana didalam Gugatan Biasa; dan (2) Bahwa dengan belum diaturnya Pelaksanaan Eksekusi terhadap Gugatan Sederhana maka akan menimbulkan tidak adanya Kepastian Hukum yang menyebabkan Gugatan sederhana tidak menjadi sesederhana sebagaimana yang diharapkan oleh Perma 2 Tahun 2015 tersebut.

\section{Daftar Pustaka}

D.Y. Wiranto, Hukum Jaminan Fidusia dalam Perjanjian Pembiayaan Konsumen (Aspek Perikata, Pendaftaran dan Eksekusi). Cv Mandar Maju Bandung, 2013 
Hans Kelsen, 1949, General Theory of Law and State Terjemahan Anders Wedberg, Harvard University Press, Massachusetts

Kementerian Perencanaan Pembangunan Nasional/ Badan Perencanaan Pembangunan Nasional, 2014, Rencana Pembangunan Jangka Menengah Nasional 2015-2019 Buku I Agenda Pembangunan Nasional, Bappenas, Jakarta

Linn Hammergren, "Diagnosing Judicial Performance: Toward A Tool To Help Guide Judicial Reform Programs", World Bank Working Paper, 2002

M. Yahya Harahap, Ruang Lingkup Permasalahan Eksekusi Bidang Perdata, PT Gramedia Puataka Utama, Jakarta, 1991

Prianter J. Hairi, "Antara Prinsip Peradilan Sederhana, Cepat dan Berbiaya Ringan dan Gagasan Pembatasan Perkara Kasasi", Jurnal Negara Hukum, Volume 2, Nomor 1, 2011

Sudikno Mertokusumo, 2007, Mengenal Hukum, Penerbit Liberty, Yogyakarta

William Penn, 1905, Some Fruits of Solitude, Headley Publisher, London 